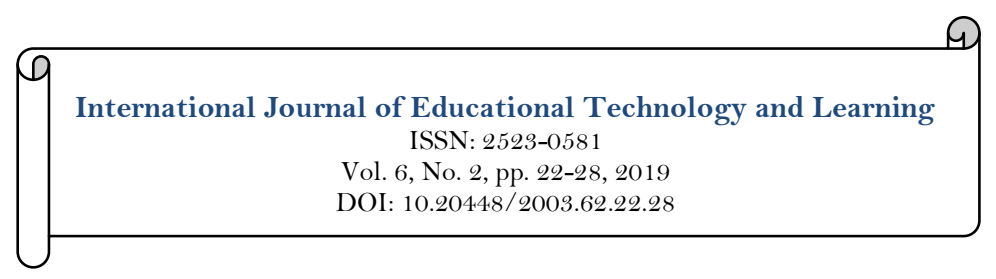

\title{
Developing Students' Sheets for Transaction Recording Materials into Special Journal of Trading Company
}

\author{
Vidia Pattashiki ${ }^{*}$ \\ Ibut Priono Leksono ${ }^{2}$ \\ Abd. Cholid ${ }^{3}$
}

'Educational Technology Department, Graduate Program, Universitas PGRI Adi Buana, Surabaya, Indonesia.

Email: vpattashiki@gmail.com

${ }^{2,3}$ Graduate Program, Universitas PGRI Adi Buana, Surabaya, Indonesia.

\begin{tabular}{l|l}
\multicolumn{3}{|c|}{ Abstract } \\
In line with the implementation of the 2013 curriculum, as it was promised by & Keywords: \\
the government that teaching materials relating to student books and teacher & Student's activity sheet \\
handbooks should be provided. However, there are no such things available yet & 2013 curriculum \\
as promised. This creates difficulties for students in learning activities and & Transaction recording material \\
teachers in teaching activities. Therefore, the purpose of this development is to & Trading company. \\
produce the final product in the form of student's activity sheet (lembar & \\
kegiatan siswa/LKS) as learning support for trading company accounting & Licensed: \\
practice material on basic competencies applying transaction records into & This work is licensed under a \\
specialized trading company journals, analyzing the feasibility of worksheets, & Creative Commons Attribution 4.0 \\
and analyzing student responses to LKS developed using types of research and & License. \\
development. A model introduced by Moelenda, ADDIE (Analysis, Design, & Publisher: \\
Development, Implementation, and Evaluation), was applied. The results & Scientific Publishing Institute \\
showed a content feasibility score of 89.36\% with very feasible criteria, the & \\
feasibility of presentation was $89.84 \%$ with very feasible criteria, language & \\
feasibility of $84.54 \%$ with very feasible criteria, and graphic eligibility of & Accepted: 5 September 2019 \\
86.66\% with fair criteria. The average four components of the study and & Published: 17 September 2019 \\
validation are 87.6\% with very feasible criteria. While the average score of the & \\
percentage of student responses is 83\% with very good criteria. So that it can & \\
be concluded that the developed worksheet is stated to be very feasible to use in & \\
the learning process and obtain a positive response from students. &
\end{tabular}

Funding: This study received no specific financial support.

Competing Interests: The authors declare that they have no competing interests.

\section{Introduction}

Education is a conscious and planned effort to realize the atmosphere of learning and the learning process so that participants can actively develop their potential. National education is one of the national development sectors in an effort to educate the nation's life. Efforts that can be made by the government in achieving national education goals are by improving the quality of education and curriculum.

Kurniasih and Sani (2014) said that Indonesian curriculum of 2013 is a series of improvements to the curriculum that have been pioneered in 2004 based on competency, then continued by the 2006 curriculum or known as the Education Unit Level Curriculum (Kurikulum Tingkat Satuan Pendidikan/KTSP). Whereas Husamah and Setyaningrum (2013) said that the 2013 curriculum is a curriculum that is developed based on the achievement of competencies that are indispensable as an instrument to direct students to: (1) quality, productive people answer the challenges of an ever changing era; (2) faith and devotion to God Almighty, capable, creative, independent, democratic and responsible. According to the Attachment of Decree of Minister of Education and Culture Kemendikbud (2013) learning in the 2013 curriculum uses a scientific approach or a 
scientific process-based approach. So that the implementation of the 2013 curriculum is curriculum actualization in learning and the formation of competencies and character of students (Mulyasa, 2013). This will require the activeness of the teacher in creating effective learning and means by actively involving students in the learning process.

Teaching materials are all material (both information, tools, and texts) compiled in a systematic manner, which displays the full figure of competency that will be mastered by students and used in the learning process with the aim of planning and reviewing the implementation of learning (Prastowo, 2014). One of the teaching materials that can be developed in the learning process is student's activities Sheet (Lembar Kerja Siswa/LKS). LKS according to the general guidelines for the development of teaching materials (Ministry of Education, 2008) are sheets containing tasks that must be done by students. This LKS contains instructions or steps to complete a task, and the task is in accordance with the basic competencies requested in the material used. Whereas according to Trianto (2013) LKS is a student guide that is used to carry out investigative activities or problem direction. In addition, according to Prastowo (2014) LKS is a printed teaching material in the form of paper sheets containing material, summaries, and instructions for implementing learning tasks that must be done by students, which refers to basic competencies that must be achieved. Tasks that can be given to students can be theoretical tasks and/or practical tasks.

Through LKS, teachers get the opportunity to lure students to be able to learn actively about the material discussed because in LKS students will get material descriptions, assignments, and practice questions related to certain material. However, there are still many students who experience difficulties because of the lack of supporting facilities in the learning process such as source books, textbooks, worksheets, and other teaching materials. Although the supporting facilities exist, the number is still limited, and one way to reduce these problems is by developing LKS.

Based on the results of interviews conducted at the State Vocational School 1, Kemlagi in Mojokerto Regency, the teaching materials used were only modules hold by the teachers, while students did not have a handbook at all. There are no teaching materials in the form of LKS, especially LKS as supporting learning materials for trading companies accounting practice has never been applied in the learning process, especially in the basic competencies in applying recording transactions into special journals of trading companies.

In general, trading company accounting material tends to relate to the execution of transaction training questions, especially in basic competencies applying the recording of transactions in journals especially in trading companies. At present, students of class XI accounting at State Vocational School 1 in Mojokerto Regency in the learning process in basic competencies apply the process of recording transactions into a specialized journal book of trading companies using only learning resources in the form of notebooks and problem exercises that are reproduced themselves. Though most students are still confused and have difficulty in learning the basic competencies of applying recording transactions in a special journal of trading companies. This happens because the available teaching materials are inadequate. So that students experience limited learning resources and also in the practice of working on the questions, students do not have an activity sheet that can be used independently.

Based on the analysis of the problem, it is necessary to develop appropriate teaching materials and support the needs of students in the learning process that are in accordance with the 2013 curriculum that can be done in the classroom or independent learning at home. And the development of worksheets as a support for learning the trading company's accounting practice material on basic competencies in applying transaction records into a special journal company of trading companies is considered appropriate to meet the needs of students in the learning process, especially in the basic competencies in registering transactions in specialized trading company journals, and as a support for other alternative teaching materials that can be used in State Vocational School 1 Kemlagi Mojokerto Regency. The development of this LKS will be designed differently from other existing teaching materials. This LKS is arranged in attractive colors in order to increase the interest and motivation of students to learn. A summary of the material in this LKS is arranged briefly with a language that is easily understood by students, so that it can build material concepts in the minds of students. In addition, the questions contained in this LKS vary greatly. The development of this LKS is expected to be able to be a reference for other learning resources by students in the learning process, so that students can gain their own understanding, especially on basic competencies in applying transaction records in specialized trading company journals, by means of independent learning such as the hopes of developing this LKS own.

Previous research on the development of LKS based on the scientific approach was conducted by Ariyanti (2014). The results of the study showed that the LKS was interesting to use on material changes in the objects around us seen from the results of LKS attractiveness test with an average percentage of $80 \%$. This shows that worksheets based on scientific approaches to class VII science subjects that have been developed are very suitable to be used as teaching materials.

Based on the problem, needs analysis, and existing empirical studies, the researcher intends to compile research in the form of LKS development as a supporter of learning in trading company accounting practice subjects. With the existence of this LKS, students are expected to be able to increase their level of understanding of the material, especially in the basic competencies in applying transaction records into special journal books for trading companies, and can shape the character of students who are more active in the 
learning process. Based on the previous studies, the researchers are interested on conducting the study on development of students' activities sheet as learning support to accounting practice material for recording transaction into special journal in trading companies.

\section{Methods}

This study used a kind of research and development known as the acronym of ADDIE (Analysis-DesignDevelop-Implementation-Evaluation) model which was introduced by Molenda (2003). From what stated by Molenda, Private (2011) further explains that the analysis step consists of two stages, namely problem analysis and needs analysis. From the two analyzes will be determined by the purpose of learning. At the design stage, design steps are needed to answer the problems that have been analyzed in the previous stage. The LKS design uses the LKS preparation format according to the 2008 Ministry of National Education reference. The development phase aims to produce teaching materials in the form of LKS. Next phase is LKS preparation stage which is from the initial draft of LKS which will then be reviewed and validated by material experts and graphic experts. While for the implementation phase, 20 students of class XI Accounting at SMK Negeri 1 Kemlagi in Mojokerto Regency were conducted. In the evaluation phase it consists of formative evaluation, namely evaluation at each stage of the development of the ADDIE model and summative evaluation which is the final evaluation of the stages of developing the ADDIE model.

The subjects of the trial in this study were material experts consisting of one economics lecturer at the Faculty of Economics, University of Surabaya PGRI Adi Buana and one accounting teacher in class XI Accounting at SMK Negeri 1 Kemlagi, Mojokerto Regency. Graphic expert consisting of one educational technology lecturer at the Postgraduate University of PGRI Adi Buana Surabaya. As well as 20 students of class XI Accounting at State SMK 1 Kemlagi Mojokerto Regency. The type of data used was qualitative and quantitative data. The instruments of data collection in this study were open questionnaires and closed questionnaires consisting of review sheets and material expert validation sheets, review sheets and graphic expert validation sheets, and student response questionnaires. To analyze the research data obtained through the research instruments, data analysis techniques were used, namely 1) the expert review sheet was analyzed descriptively qualitatively to provide description from the suggestions and input given to the deficiencies in the preparation of worksheets related to the content, presentation, language, and graphics; 2) the experts' validation sheet was analyzed quantitatively by using the percentage technique obtained based on the calculation of scores according to the Likert Scale (Riduwan, 2013) student response questionnaires were analyzed quantitatively in the form of choices "Yes" and "No" based on the Guttman scale (Riduwan, 2013).

\section{Results and Discussion}

The presentation of the results of this development aims to answer the formula for problems that have been previously set. The following are the results of research on the development of worksheets as supporting learning of trading company accounting practice material on basic competencies in applying transaction records into a special journal book of trading companies of class XI accounting at State Vocational High School 1 Kemlagi, Mojokerto Regency.

\subsection{The Development Process of LKS}

The development of this LKS used the ADDIE (Analysis-Design-Development-ImplementationEvaluation) development model through five stages of development which consist of the analysis, design, development, implementation and evaluation stages. In the analysis phase, data collection and analysis of information is carried out to define the problem and make a follow-up plan in the initial design of the LKS of the special journal of the trading company to be developed. There are three activities carried out at this stage, namely problem analysis, needs analysis, and formulation of learning objectives. The results of the development of worksheets as a support for learning the trading company's accounting practice material on basic competencies apply the recording of transactions into a special journal book of trading companies of class XI Accounting in the State Vocational School 1 Kemlagi Mojokerto Regency are as follows:

i. Analysis Phase

Analysis is the first step in the ADDIE development model. Private (2011) states that the analysis step consists of two stages, namely problem analysis and needs analysis. From these two things will be determined the purpose of learning. These activities can be explained as follows:

1) Problem Analysis

Problem analysis aims to define the situation that occurs in the field and raises the basic problems needed by the researchers in developing Student Activity Sheets (LKS) as supporting learning in the basic competencies of applying transaction recording into specialized trading companies' journal books. From the results of the analysis obtained information that SMK Negeri 1 Kemlagi is one of the vocational high schools that has a field of business and management expertise in Mojokerto Regency. The field is the most preferred subject for students, especially in the Kemlagi sub-district, Mojokerto 
Regency. SMK Negeri 1 Kemlagi in Mojokerto Regency has implemented the 2013 curriculum since the even semester of the 2013/2014 academic year, but the application of the 2013 curriculum had stopped for one year of the learning process because it was not supported by adequate facilities and infrastructure. In the implementation of the 2013 curriculum, learning support devices such as teaching materials in the form of modules have not all used the 2013 curriculum. This is because the government has not fully fulfilled the needs of learning tools in the 2013 curriculum, as well as the majority of disadvantaged teachers in developing their own teaching materials. So that the teacher will find it difficult to find teaching materials that are in accordance with the 2013 curriculum. Based on the results of interviews with teachers and students, it can be concluded that the teaching materials used by the teacher are only in the form of teacher-only modules. Students do not have their own handbooks. Therefore, for the material for the training, students are given sheets containing questions which will then be reproduced by each of the students themselves. Teaching materials in the form of LKS do not yet exist in the State Vocational Schools 1 in Mojokerto Regency, especially LKS that are used as learning support for trading company accounting practice materials on basic competencies applying recording transactions into specialized trading companies' journal books. These LKS have never been applied in trading company accounting practice learning, especially in basic competencies apply the process of recording transactions into a specialized journal book of trading companies.

2) Need Analysis

Based on the analysis of the above problems, it is necessary to develop an appropriate teaching material and be able to support the needs of students in the learning process in accordance with the 2013 curriculum, in which the curriculum is tried and done, which can be done in class or learning independently that can be done at home. The development of worksheets that support the implementation of the 2013 curriculum is appropriate to meet the need of students during the learning process, especially in the basic competencies in applying transaction records into specialized trading companies' journal books, as a complement to other alternative teaching materials that can be used in State Vocational Schools 1 Kemlagi Mojokerto Regency. Therefore, it can be concluded that teachers and students need teaching materials that are in accordance with the 2013 curriculum.

3) Learning Objectives

The results of the formulation of learning objectives for material applying the recording of transactions into a special journal book of trading companies would be the basis for the preparation of the LKS design. Learning indicators in the third Basic Competency (Kompetensi Dasar/KD) regarding the knowledge that must be achieved by students in the material applying the recording of transactions into a special journal of trading companies after studying the basic competency applying recording transactions into a special journal book of this trading company are expected by students that can: 1) explain the definition of a special journal; 2) explain the functions of special journals; 3) preparing trade company transaction documents; 4) identify sales transactions; 5) identify cash receipt transactions; 6) identify purchase transactions; 7) identify cash disbursement transactions; 8) identify other general transactions

ii. Design Phase

At this stage, the draft LKS was made by initiating the preparation of the LKS format. The format of this LKS follows the 2008 Ministry of National Education format reference. The format of the LKS preparation starts from the front cover to the back cover. The core part of this LKS is the introduction, the contents section, and the closing section. The introduction consists of introductory words, table of contents, and learning instructions. The content section consists of core competencies and basic competencies, subject matter, and learning objectives, material about understanding and learning objectives, material about the definition and function of special journals, understanding of each special journal and sample questions, and presentation of varied evaluation questions. At the end, the closing section will be presented in the literature section and ended with the back cover in the form of a profile of the LKS compiler.

iii. Developing Phase

The draft LKS that has been made in the previous stage would then be realized in this stage of development, so as to produce the first draft which was then reviewed by material experts and graphic experts. Then it would be revised by the researchers based on advice and input from the experts. After revising and evaluating the results of the expert's review, then the LKS will be validated by material experts and graphic experts to find out the feasibility of the LKS developed by the researcher so that it finally produced the second draft which was ready to be tested on a small scale of students to find out their responses. 
In the implementation phase, the second draft in the form of LKS products as a learning support for basic competencies in applying transaction records in special trading company journals was tested on a small scale of 20 students of class XI Accounting at State Vocational School 1 Kemlagi Mojokerto Regency to find out responses and student opinions on the developed of LKS.

\section{v. Evaluation Phase}

The last stage was a feasibility evaluation to see whether the product developed was successful, in line with expectations or not. From the validation of material experts and graphic experts, as well as student response questionnaires from small-scale trials, data analysis was carried out which was then used to prepare LKS development reports to support learning in basic competencies in applying transaction records in specialized trading company journals for class XI Accounting in State Vocational School 1 Kemlagi, Mojokerto Regency.

\subsection{The Feasibility of LKS}

The feasibility of LKS is measured by the assessment of material experts and graphic experts found in the validation sheet of material experts and graphic experts. Validator of material experts consists of one economics lecturer at the Faculty of Economics, Universitas PGRI Adi Buana Surabaya and Accounting teachers at State Vocational School 1 Kemlagi, Mojokerto Regency. While for the graphic expert validator consisted of one lecturer of Educational Technology department of Graduate Program of Universitas PGRI Adi Buana Surabaya. Evaluation of the feasibility of the worksheet developed about the content, presentation, language, and graphics were seen from the reference given by National Professional Certification Body (Badan Nasional Sertifikasi Profesi/BSNP).

From the results of the validation of the experts, the calculation of the presentation from the four components of feasibility was obtained. Then, the percentage calculation results are interpreted with qualitative sentences. The results of the expert validation of the developed worksheets are as follows:

\begin{tabular}{llll}
\multicolumn{3}{c}{ Table-1. } & Expert validation result. \\
\hline No. & Component & Percentage (\%) & Criteria \\
\hline 1. & Content feasibility & $89.36 \%$ & Most feasible \\
\hline 2. & Presentation feasibility & $89.84 \%$ & Most feasible \\
\hline 3. & Language feasibility & $84.54 \%$ & Most feasible \\
\hline 4. & Graphical feasibility & $86.66 \%$ & Most feasible \\
\hline Average & $87.60 \%$ & Most feasible \\
\hline Source: Data processed (2018). & &
\end{tabular}

Based on Table 1, the results of the material expert validation sheet in terms of components of content feasibility obtained a percentage of $89.36 \%$ with the criteria "Most Feasible". Based on these results indicates that the LKS developed contains material and questions contained in accordance with the criteria that have been determined in accordance with the core competence (Kompetensi Inti/KI) and basic competence (Kompetensi Dasar/KD) and learning objectives.

The component of presentation feasibility obtained a percentage of $89.84 \%$ so that it was included in the criteria of "Most feasible", meaning that the systematic consistency of presentation in the LKS was in accordance with the development of LKS in general. There is an introduction that contains instructions for learning, core competence, basic competence, subject matter, and learning objectives. The content section consists of pictures, illustrations, presentation of material by including a $5 \mathrm{M}$ approach, concise material, and sample examples. While the evaluation section consists of questions in the form of essay questions, transaction proof settlement questions, multiple choice questions, and final learning questions in the form of group observations. In addition, there is also a table of contents and bibliography.

The component of language feasibility obtained a percentage of $84.54 \%$ with the criteria "Most Feasible". The acquisition explains that the language used in the preparation of worksheets is in accordance with the level of development of students' thinking, the terms used are in accordance with the Big Indonesian Dictionary. The sentence arrangement on the LKS also complies with the Improved Spelling (Ejaan Yang Disempurnakan/EYD) guidelines. This is supported by the use of language in LKS which refers to the rules of Indonesian language that are good and correct, meaning that all teaching materials must pay attention to linguistic components in accordance with aspects of sub-language linguistic feasibility, so the accuracy of sentence structure and systematic arrangement of materials will facilitate students in understanding learning material (Ministry of Education, 2008).

The component of graphical feasibility obtained a percentage of $86.66 \%$ with the criteria "Most Feasible". This acquisition shows that the LKS developed has a size according to the ISO standard, the composition of the layout is proportional, balanced, and in line with the layout of the contents. This is supported by the attractiveness of colors and design illustrations on the LKS cover as well as the contents of the LKS, so as to 
clarify the concepts, messages, and material presented in the LKS. Attractive illustrations coupled with the right layout can make teaching materials more harmonious and interesting to learn and can motivate students to use teaching materials in the learning process. This shows interesting color and illustration combinations play an important role in teaching materials (Ministry of Education, 2008).

The overall results of LKS validation based on four components from experts obtained an average percentage of $87.60 \%$, it can be concluded that the development of worksheets as supporting learning in basic competencies applies recording transactions into specialized trading company journals for accounting class XI students at State Vocational Schools Kemlagi 1 Mojokerto Regency is declared "Most Feasible" to be used in the learning process, because with these results it shows that the LKS developed is in accordance with the assessment of the BSNP that fulfills the feasibility of content, presentation, language, and graphics.

\subsection{Student's Response toward LKS}

After being reviewed and validated, the researchers then conducted a small-scale trial. Small-scale trials were conducted to test the LKS product and find out student responses to student worksheets developed in 20 students of class XI accounting at State Vocational School Kemlagi 1 Mojokerto Regency.

The researcher gave a closed questionnaire in the form of student response questionnaires to be filled out by students in order to find out the extent to which students' responses to using LKS on basic competencies apply recording transactions into special journals of trading companies. From the results of the student questionnaire responses, the average percentage was obtained which was then interpreted with qualitative sentences. The following are the results of the student questionnaire responses to the worksheet developed

Table-2. Questionnaire results of student's responses

\begin{tabular}{l|l|l|l}
\hline No. & Assessed criteria & Percentage (\%) & Remark \\
\hline 1. & Content criteria & $97.5 \%$ & Excellent \\
\hline 2. & Presentation criteria & $67.5 \%$ & Good \\
\hline 3. & Language criteria & $80 \%$ & Good \\
\hline 4. & Graphical criteria & $87 \%$ & Excellent \\
\hline \multicolumn{2}{l}{ Overall average score } & $83 \%$ & Excellent \\
\hline
\end{tabular}

Based on Table 2, for the results of student responses to the developed LKS, the percentage results were $83 \%$ with the criteria of "Excellent". This shows that students' responses to worksheets developed are seen from the content, presentation, language, and graphics are very good. Similar research was conducted by Rosida (2015) that the LKS developed was the most feasible with the acquisition of $84.43 \%$ percentage based on the assessment of the experts and the students' responses showed very good criteria with the acquisition of $86.25 \%$.

\section{Conclusions}

Based on the development process that has been carried out to produce teaching material products in the form of student activity sheets (LKS) as supporting learning of trading company accounting practice material on basic competencies applying transaction recording into specialized trading company journals, and analysis of research data obtained, it can be concluded that: 1) this development produces a product in the form of a student activity sheet (LKS) as a support for learning the trading company's accounting practice material on basic competencies in applying transaction records into a special journal of trading companies. The development process is in accordance with the ADDIE (Analysis-Design-Development-ImplementationEvaluation) development model through five stages of development which consist of the analysis, design, development, implementation and evaluation stages, 2) the feasibility of worksheets on the basic competencies of trading company specific journals in terms of the validation of material experts and graphic experts obtain very feasible results to be used as learning teaching materials with an average validation score of material experts of $87.91 \%$ which shows very feasible criteria and the average score for the validation of the graphic expert is $86.66 \%$ which indicates the criteria are very feasible, and 3) Students' responses to worksheets developed on the basic competencies of applying transaction records into special trading company journals obtain good results used as teaching materials as indicated by the average percentage of student responses of $83 \%$ which shows very good criteria.

\section{Suggestions}

Based on the conclusions above, the suggestions related to the development that have been carried out include: 1) researchers can test the application of the worksheet to find out its effectiveness so that it can complement the research results that the student's worksheet developed is not only very feasible to use but also effective to apply, and 2) LKS developed in this study is limited to the basic competencies in applying the recording of transactions into a special journal of trading companies. For further researchers who want to do similar research can be developed for other basic competencies. 


\section{References}

Ariyanti, D. N. (2014). Development of student approach worksheets based on scientific approach subjects for class VII natural sciences in Bandar Lampung.

Husamah, \& Setyaningrum, Y. (2013). Design learning based on competency achievement. Jakarta: Achievement of the Librarian.

Kemendikbud. (2013). Permendikbud number 103 of 2014 concerning learning in basic education and secondary education. Jakarta: Ministry of Education and Culture Republic of Indonesia.

Kurniasih, I., \& Sani, B. (2014). Implementation of the 2013 concept \& implementation curriculum. Surabaya: Pena Words. Ministry of Education. (2008). Guidelines for development of teaching materials. Jakarta: Ministry of National Education.

Molenda, M. (2003). In search of the elusive ADDIE model. Performance Improvement, 42(5), 34-37.

Mulyasa, H. E. (2013). Curriculum development and implementation 2013. Bandung: PT. Teen Rosdakarya.

Prastowo, A. (2014). Creative guide to making innovative teaching materials. Jogjakarta: Diva Press.

Private, B. A. (2011). Learning system design model. Jakarta: Dian Rakyat.

Riduwan. (2013). Measurement scale of research variables. Bandung: Alfabeta.

Rosida, I. (2015). Development of scientific approach-based modules as supporting teaching materials for the implementation of the 2013 curriculum on the main material use of special journals at SMK Negeri Mojoagung. Journal of Accounting Education (JPAK), 3(2), 39-52.

Trianto. (2013). Designing innovative-progressive learning models: Concepts, foundations and their implementation in the education unit level curriculum (SBC). Jakarta: Kencana Prenada Media Group. 